UDK 618.11-006.6-08

CASE REPORT

\section{Giant Mucinous Ovarian Cystadenocarcinoma}

\begin{abstract}
Mucinous cystadenosarcoma make $10 \%$ of ovarian cancers. They are among the largest ovarian tumors measuring up to $50 \mathrm{~cm}$ in diameter. We want to show a case of a female patient aged 69 years, who was brought to surgery due to the large abdominal mass, abdominal growth noticed four months earlier, with prior weight loss. After CT examination of the abdomen, we found extremely distended abdominal cavity, filled with coarse grained content, with apparent suspicion of tumor of the abdomen of ovarian origin. During the surgery, the following operations were performed: extirpation of the cyst sized $80 \times 80 \times 80 \mathrm{~cm}$, right adnexectomy, partial resection of the uterus, the reconstruction of the right ureter with the previous placement of double $\mathrm{J}$-stent, and the reconstruction of the anterior abdominal wall. The postoperative course was uneventful. Pathohisthological diagnosis confirmed cystadenocarcinoma mucinosum invasive partim inflammatum ovary, G1, pT1a. The tumor morphologically corresponded to multicystic, well-differentiated invasive mucinous adenocarcinoma with parts that have the characteristics of mucinous tumor with the border degree of malignancy. Since the diagnostic and therapeutic procedures did not elucidate the origin of the tumor mass, and gynecologicaloncological principles were not respected in terms of radicalism, the patient was proposed a new surgical procedure that would imply a total hysterectomy and left adnexectomy, which was refused by the patient. Medical check-up after 12 months did not confirm disease recurrence.
\end{abstract}

Key words: ovarian cystadenocarcinoma, mucynous, giant

DOI: 10.7251/SMDEN1501076K

(Scr Med 2015:46:76-79)

\section{Ferid Konjić, ${ }^{1}$ Zijah Rifatbegović', Mirela Pirić1, Šefik Hasukić ${ }^{1}$}

${ }^{1}$ Department of Surgery, University Clinical Center Tuzla, Bosnia and Herzegovina

\section{Contact:}

Dr. Ferid Konjić

Department of Surgery,

University Clinical Center Tuzla,

Bosnia and Herzegovina

Tel: o61 179118

E-mail: konjic.ferid@gmail.com

Submitted: January 22th, 2015

Accepted: March 3rd, 2015

\section{Introduction}

Ovarian cancer, as the disease of highly developed socioeconomical societies, is the sixth disease according to the incidence, in comparison to other malignancies in female population, with around 205.000 new cases per year. According to the incidence in the field of gynecologic oncology, it is the second malignancy, and it is the second in the world when speaking about mortality rate with absolute number of 125.000 deaths per year. ${ }^{1}$ Mucinous cystadenocarcinoma makes $10 \%$ of ovarian cancers. They belong to the largest ovarian tumors with dimensions up to $50 \mathrm{~cm}$ in diameter. One quarter of these tumors has a bilateral localisation. ${ }^{2}$
In a typical history of ovarian cancer the following symptoms can be found: abdominal pain (53\%), increase of the abdominal volume (46\%), difficult and frequent urination (39\%), feeling of satiety (22\%), vaginal bleeding (14\%), obstipation (17\%), and weight loss despite the increased and distended abdomen. ${ }^{3}$

Taylor et al reported that around 10\% of all cases of ovarian carcinoma are genetically predisposed. ${ }^{4}$ Namely, positive family history in terms of breast cancer and ovarian cancer, especially in younger age, may indicate the presence of BRCA1 (chromosome 17) and BRCA2 (chromosome 13) of genetic mutation in patients from such families. ${ }^{4}$ This type of 
carcinoma is detected earlier than the more frequent serous type of ovarian epithelial carcinoma, thus leading to a better perspective. However, females with advanced mucinous ovarian tumor have much worse perspective in comparison to those with advanced serous ovarian tumor. Scientists believe that the possible explanation lays in the fact that the mucinous ovarian carcinoma is biologically different than the serous, and that it is more similar to carcinoma of gastrointestinal tract, such as the colorectal cancer. ${ }^{5}$

\section{Case report}

A 69-year-old female was reported to the surgical clinic with the huge abdominal mass in November, 2013. She noticed the sudden stomach growth within the previous four months, with previous weight loss and the loss of appetite. She stated earlier problems with diverticula related diseases and hiatal hernia in the stomach. She did not give birth. Menopause occurred at the age of 53. She denied the usage of tobacco and alcohol.

After physical examination, it was found that the patient was hemodynamically and respiratory stable, with medium osteomuscular material, pale skin, afebrile $\mathrm{T}=36,5$ Celsius degree; blood pressure 170/100 mmHg; pulse of 100 beats per minute; with normal findings on the respiratory and cardio-vascular system. The abdomen was enormously enlarged to volume of the $70 \mathrm{~cm}$, above the chest level, tight skin with prominent subcutaneous venous drawings, painless to palpation (Figure 1.). The patient was stagnant due to the large abdominal mass.

Figure 1. Pre-surgical examination: enormously enlarged stomach of the patient.

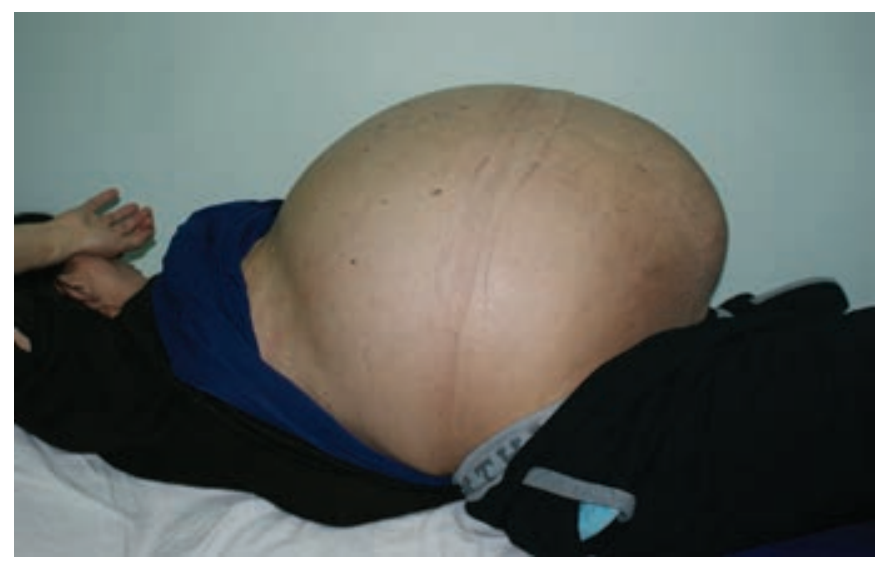

Laboratory findings showed hypokalemia, hyperazotemia (K $3,7 \mathrm{mmol} / \mathrm{l}$, Urea $10.30 \mathrm{mmol} / \mathrm{l}$ ). X-Ray showed enormous soft tissue mass on the subdiaphragmathic abdomen and the lower part of thorax, which significantly suppressed the diaphragm and the heart shadow. The CT of the abdomen was done, and it showed the extremely distended abdominal cavity, replete with coarse grained content, most probably thick gelatin which was monitored directly under the liver and spleen caudal to the bowl, lifting the front abdominal wall. Transversal diameter of the above-stated formation was over $50 \mathrm{~cm}$. In continuity with the left adnexa cranially, above the entrance into the upper pelvic area, resting on to the bowl wall posteriorly repressed column, there was inhomogeneous mixed density which could have corresponded to the left ovary. However, an intimate contact with the descendent column included voluminous, imbibed mesocolon. The abovementioned formation had a transversal diameter of $7 \mathrm{~cm}$. Almost identical formation which was present at the right rib arch, was present on the wall of the compressed and repressed column. Taking into consideration the abovestated, we decided to perform exploratory laparotomy. Intraoperatively, the large cystic tumor sized 80 x 80 x 80 cm was found, and then opened forehand. (Figure 2.)

Figure 2. Stuffed massive cyst in the abdomen

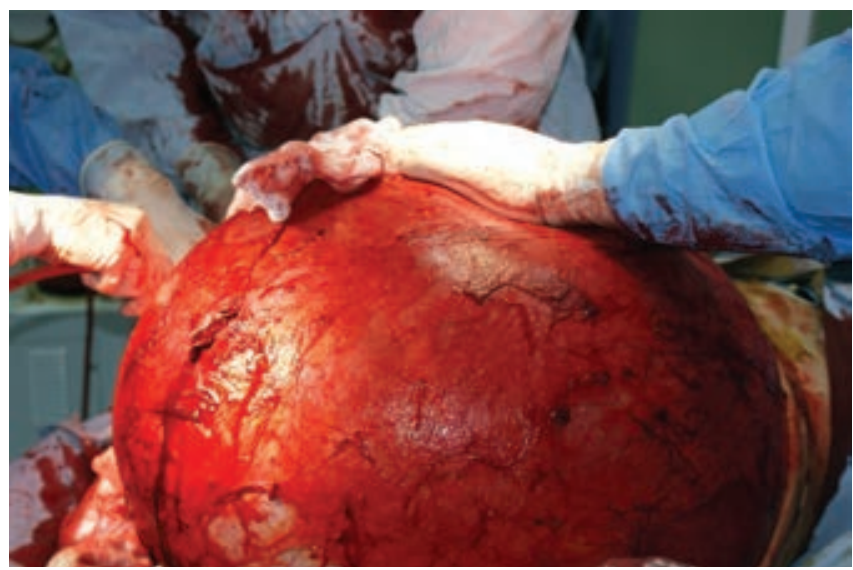

Figure 3. Ureter reconstruction

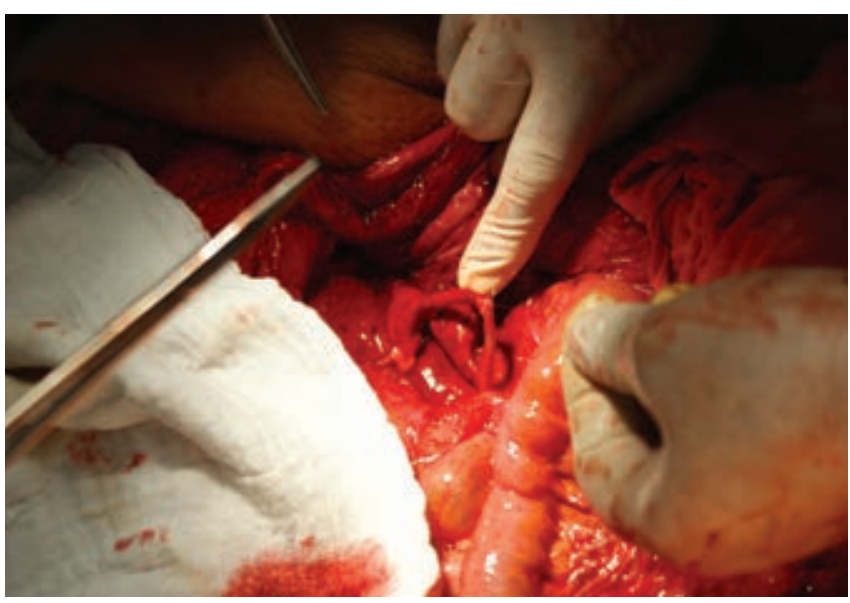

The cyst contained large amount of brownish turbid liquid. The wall of this cyst contained two necrotic formations one was men's fist sized, and the other tangerine-sized. Cyst adhered to the lateral wall of uterus and the right adnexa gave the impression that the above-stated mass was of 
ovarian origins. On the liver macroscopically and palpatory there were no secondary deposits. Cyst extirpation was performed, together with the right adnexectomy, partial uterus resection, omentectomy, and due to the iatrogenic lesion the ureter suture with the preceding, stent placement was performed (Figure 3.).

The surgery was completed with the plastic and front stomach wall reconstruction (Figure 4.).

Figure 4. Appearance and the reconstruction of abdominal cavity after the massive cyst extirpation from the stomach cavity

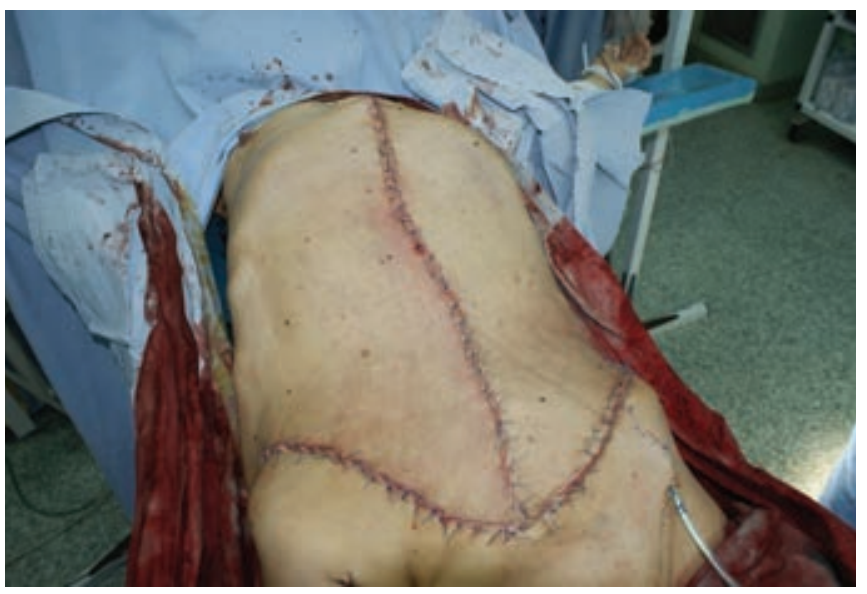

Pathohystological diagnosis cyctadenocarcinoma mucinosum invasivum ovary, G1, pT1a. By its morphological structure, tumor corresponded to the multicystic, well-differentiated invasive mucinous adenocarcinoma with parts that had the characteristics of mucinous tumor of borderline malignity degree. The patient spent early post-surgery period at the Intensive care unit, due to the intensive hemodynamic, respiratory and renal monitoring. Taking into consideration the fact that diagnostical and therapeutical procedures did not elucidate the origins of the tumor mass, as well as the fact that the gynecological and oncological principles were not respected in the sense of radicalness, the patient was suggested to visit the gynecologist who proposed the continuation of adjuvant chemotherapy and another surgery which implied total hysterectomy and the left adnexectomy, which was rejected by the patient. Proposed chemotherapy was also rejected by the patient. Post-surgery monitoring during the period of 12 months (CT of abdomen, tumor markers, KKS, SE, UZ of abdomen) showed that there were no signs of the advanced disease.

\section{Discussion}

Ovarian cancers are considered to be the largest problem in the field of gynecologic oncology. The main reason lays in the fact that the early diagnosis is impossible, thus, the only option is to make the diagnosis in the advanced stadium of this disease. The early detection of this disease requires a reliable screening test. Nowadays three screening techniques are available: pelvic examination, CA-125 level and the vaginal ultra-sound which mainly does not establish the ovarian cancer but do suggest its presence. ${ }^{6}$

Ovarian cysts are considered large if they are 10 and $20 \mathrm{~cm}$ in diameter, ${ }^{7}$ and in cases when they cross these dimen sions, they are considered gygantic cysts. Gygantic cystadenocarcinoma are rare clinical states. The largest removed ovarian tumor that was recorded in literature had a weight of $137,4 \mathrm{~kg}$ and it was removed in the form of intact mass by O'Hanlan. ${ }^{8}$ Also, ovarian adenocarcinom with the weight of $64 \mathrm{~kg}$ was described by Pool et al. and it was removed from an obese female. ${ }^{9}$ Mattioda de Lima et al. published their removal of cystadenocarcinom of weight $40 \mathrm{~kg}$ from a 57-year-old Brazilian female. ${ }^{10}$ In a 52-year-old female in the post-menopause period, a solid bilateral ovarian mass was diagnosed and removed with the size of right $25 \times 30 \mathrm{~cm}$, and left $15 \times 12 \mathrm{~cm}$, with weight $6.5 \mathrm{~kg}$. Pathohystologically ovarian adenocarcinoma was confirmed by Satpathy. ${ }^{11}$

Regardless the pathohystological diagnosis, gygantic cysts require surgery treatment because of the compressive symptoms, malignant alteration risks and the preventions of the cyst burst, thus shedding the cyst liquid into the stomach cavity. ${ }^{12}$ Females with the tumor mass in their stomach cavities are a huge challenge in a daily practice, above all due to the silent and unspecific clinical signs of tumor. Accompanying signs of obesity are aggravating factor.

Although the growth of tumor markers CEA, CA 19-9, CA125 , alphafeto-proteins can be very useful in the differential diagnosis of malignant cystic tumors, they can also be increased in benign tumors. Cevik et al. published the removal of a large mucinous cystadenoma of the left ovary with dimensions of $40 \times 30 \times 20 \mathrm{~cm}$ with the higher value of tumor marker from a 13-year-old girl. ${ }^{13}$

Survival rate with the ovarian cancers is $30 \%$, and this rate has not significantly changed within the last 30 years. ${ }^{14}$ The data show a significant connection between the disease stage, diagnosis and the five-year survival. Rate of patients diagnosed in the stadium I, when the tumor is localized on to the ovary, varies between 22 and $28 \%$, with the survival rate between 72 and $81 \%$. Survival rate for most of the patients in the stadiums II to IV is significantly worse. ${ }^{15}$

Literature shows that patients with the optimal tumor reduction, despite the advanced stage of disease, have middle survival rate with 39 months of survival, in comparison to 17 months of survival of patients with sub-optimal surgeries. ${ }^{16}$ However, retrospective analysis results of 349 patients with post-surgery residual mass smaller or equal to $1 \mathrm{~cm}$ suggest that patients with advanced disease stage with tumor reduction have a worse outcome than the patients with the early disease stage. ${ }^{17}$ Standard post-surgery therapy implies chemotherapy with cisplatin/paclitaxel or substitution of paclitaxel with cyclophosphamide for the advanced stages of the disease. ${ }^{18}$ 
Taking into consideration the fact that diagnostical and therapeutical procedures did not elucidate the origins of the tumor mass, as well as the fact that the gynecological and oncological principles were not respected in the sense of radicalness, the patient was suggested another surgery which implied total hysterectomy and left adnexectomy, which was rejected by the patient. Proposed chemotherapy was also rejected by the patient. Despite this, one year after the surgical treatment there were no signs of disease recurrence.

\section{Conclusion}

Diagnosis of the ovarian cancer in its early stage is very difficult. In fact, at the moment of diagnosis, most of them are ate the advanced stage. Pathohistological diagnosis, disease stage, aggressive surgical treatment are, when possible, part of initial evaluation and the ovarian cancer treatment. Although in this concrete case the diagnosis was late, cystadenocarcinoma was still removed before dissemination.

\section{References}

1. Ferlay J, Bray F, Pisani P, Parkin DM. GLOBOCAN 2002: cancer incidence, mortality and prevalence worldwide. IARC Cancer Base No5, version 2.o. Lyon: IARC Press; 2004.

2. Veljkov M., Radović M., Pop-Trajković Z.,Todorović B., Mijović D.,Katić V., Kliničke karakteristike i dijagnostika epitelijalnih ovarijalnih tumora, Acta medica Medianae 2002; 435-450.

3. Colombo N, Van Gorp T, Parma G, Amant F, Gatta G, Sessa C, Vergote I., Ovarian cancer. Crit Rev Oncol Hematol 2006; 60 (2):159179.

4. Taylor S, Kirwan J. Ovarian cancer: current management and future directions. Obstet Gynaecol Reprod Med 2009;19(5): 130-135.

5. Schiavone MB, Herzog TJ,Lewin SN, Deutsch I. And al. American Journal of Obstetrics \& Gynecology 2011; 2015 (5): 480.

6. Žikić D, Mandić A, Popović M, Koprivšek K,Panjković M. Arch Metastatic spread of mucinous cystadenocarcinoma of the ovaries into abdominal wall. Oncol 2005; 13 (2): 86-88.
7. Göçmen A, Atak T, Uçar M, Sanlikal F. Laparoscopy-assisted cystectomy for large adnexal cysts. Arch Gynecol Obstet. 2009; 279:17-22. doi: 10.1007/s00404-008-0651-2.

8. O'Hanlan KA. Resection of a 303.2-pound ovarian tumor. Gynecol Oncol. 1994; 54:365-371. doi: 10.1006/gyno1225.

9. Poole SY, Malone JM Jr, Jacques SM, James A. Giant mucinous ovarian tumor with low malignant potential with foci of well-differentiated mucinous adenocarcinoma masked by massive obesity. A case report. J Reprod Med. 1994;39:982-984.

10. De Lima SHM, dos Santos VM, Darós AC, Campos VP, Modesto FRD. A 57-year-old Brazilian woman with a giant mucinous cystadenocarcinoma of the ovary: a case report. Journal of Medical Case Reports 2014;8:82. doi:10.1186/1752-1947-8-82.

11. Satpathy P, Jaiswal and Jaiswa P. Obstet Gynaecol India. Dec 2012; 62(1): 52-53.

12. Dolan MS, Boulanger SC, Salameh JR. Laparoscopic management of giant ovarian cyst. JSLS. 2006;10:254-256.

13. Cevik M, Guldur ME. An extra-large ovarian mucinous cystadenoma in a premenarchal girl and a review of the literature. J Pediatr Adolesc Gynecol. 2013; 26: 22-26. doi: 10.1016/j.jpag.2012.04.007.

14. Black R, Sharp L, Kendrick S. Trends in cancer survival in Scotland 1968-90. Edinburgh:Information and Statistics Division, NHS Scotland, 1993 .

15. Kosary C. FIGO stage, histology, histologic grade, age and race as prognostic factors in determining survival for cancers of the female gynaecological system. Semin Surg Oncol 1994; 10:31-46.

16. Hoskins WJ. Surgical staging and cytoreductive surgery of epithelial ovarian cancer. Cancer 1993;71(4):1534-1540.

17. Hoskins WJ, Bundy BN, Thigpen JT. The influence of cytoreductive surgery on recurrence-free interval and survival in small-volume stage III epithelial ovarian cancer: a Gynecologic Oncology Group study. Gynecologic Oncology 1992;47(2):159-166.

18. Piccart MJ, Bertelsen K, James K, Cassidy J, Mangioni C, Simonsen $\mathrm{E}$, et al. Randomized inter group trial of cisplatin-paclitaxel versus cisplatin-cyclophosphamide in women with advanced epithelial ovarian cancer: three-year results. J Natl Cancer Inst 2000; 92(9): 699-708.

\section{Gigantski mucinozni cistoadenokarcinom jajnika}

\section{SAŽETAK}

Mucinozni cistadenokarcinomi čine 10\% ovarijalnih karcinoma. Oni spadaju u najveće ovarijalne tumore dimenzija i do 50 cm u prečniku. Želimo pokazati slučaj žene stare 69 godina koja se javila u hirušku ambulantu prvenstveno zbog velike abdominalne mase, rasta trbuha primijećenog unazad četiri mjeseca, uz prethodni gubitak tjelesne težine. CT pregledom abdomena utvrdili smo ekstremno distendiranu abdominalnu šupljinu, ispunjenu grubo zrnatim sadržajem, sa očiglednom sumnjom na tumor abdomena ovarijalnog porijekla. Tokom operativnog zahvata izvedena je ekstirpacija ciste dimenzija 80x80x80 cm, desna adneksektomija, parcijalna resekcija uterusa, rekonstrukcija desnog uretera sa prethodnim plasiranjem double $\mathrm{J}$ stenta te rekonstrukcija prednjeg trbušnog zida. Postoperativni tok bio je uredan. Patohistološka dijagnoza potvrdila je cyctadenocarcinoma mucinosum invasivum partim inflammatum ovary, G1, pT1a. Tumor je morfologijom odgovarao multicističnom, dobro diferenciranom invasivnom mucinoznom adenokarcinomu sa dijelovima karakteristika mucinoznog tumora graničnog stepena maligniteta. Obzirom da dijagnostički i terapeutski postupci nisu rasvijetlili porijeklo tumorske mase te da ginekološki onkološki principi nisu ispoštovani u smislu radikalnosti, pacijentici je predložen novi operativni zahvat koji bi podrazumijevao totalnu histerektomiju i lijevu adneksektomiju, ali je pacijentica odbila. Kontrola pacijentice nakon 12 mjeseci nije potvrdila recidiv bolesti. 